Söğüt, S. (2018). Gender representations in high school EFL coursebooks: An investigation of job and adjective attributions. Abant İzzet Baysal Üniversitesi Ĕ̈itim Fakültesi Dergisi, 18 (3), 1722-1737.

Geliş Tarihi: 13/12/2017

Kabul Tarihi: 07/06/2018

\title{
GENDER REPRESENTATIONS IN HIGH SCHOOL EFL COURSEBOOKS: AN INVESTIGATION OF JOB AND ADJECTIVE ATTRIBUTIONS
}

\begin{abstract}
Sibel SÖĞÜT*
ABSTRACT

Gender-biased representations in coursebooks have the potential to affect learners and teacher in terms of their attitudes, mindsets, and values. Considering the crucial importance of the coursebooks in Turkish educational context, the present study aims to shed light on the distribution of the gender roles in the coursebooks by examining job and adjective attributions. Within the scope of this aim, the data of the study consist of high school EFL coursebooks and workbooks published by the Turkish Ministry of National Education. In the data analysis procedure, a frequency count was done to identify a number of roles attributed to female and male characters. In this respect, the frequencies of jobs and adjective attributions of male and female characters were determined by counting the tokens. In the following step, jobs and adjectives attributed to female and male characters are classified and compared. As a result of the analysis, female and male characters in the coursebooks differ from each other in terms of both the number and variety of jobs attributed to them in spite of some similar jobs (e.g., teacher, doctor, architect) and adjectives (e.g., famous, thoughtful, successful) attributed to both genders. The possible reasons underlying the aforementioned differences are discussed and explained in detail by taking the Turkish educational and social setting into consideration.
\end{abstract}

Key Words: Gender representation, gender roles, coursebooks, job and adjective attributions

\section{INNGILIZCE LISE DERS KITAPLARINDA CINSIYYET TEMSİLI: MESLEK VE SIFAT GÖSTERIMLERİ ÜZERİNE BİR INCELEME}

\section{ÖZET}

Ders kitaplarındaki cinsiyet yanlılığını hem öğrencilerin hem de öğretmenlerin tutumlarını, zihniyetlerini ve değerlerini etkileme potansiyeline sahiptir. Türk eğitim bağlamında ders kitaplarının önemi göz önünde bulundurulduğunda, bu çalışma, lise düzeyinde okutulan İngilizce ders kitaplarında cinsiyet rollerinin meslek ve sıfat gösterimlerini incelemeyi hedeflemektedir. Bu amaç doğrultusunda, çalışmanın verisi lise düzeyinde okutulan İngilizce çalışma ve alıştırma kitaplarından oluşmaktadır. Çalışmanın veri analiz sürecinde ders kitaplarındaki metinlerde kadın ve erkek cinsiyet rollerine atfedilen meslek ve sıfat gösterimlerinin sıklıkları sayılmıştır, bu bağlamda kadınlara ve erkeklere yüklenen meslek ve sıfatlar saptanmıştır. Sonraki aşamada ise kadın ve erkeklere yüklenen meslek ve sıfat gösterimleri sınıflandırılmış ve karşılaştırılmıştır. Çalışmanın sonucunda, mesleklerde (ögretmen, doktor, mimar, vb.) ve sıfatlarda (ünlü, düşünceli, başarıll, vb.) cinsiyet dağılımlarındaki birtakım benzerliklere karşın kadın ve erkek rollerinin çalışma kapsamında incelenen bütün kitaplarda cinsiyetlere yüklenen meslek ve sıfatların hem sayı bakımından hem de çeşit bakımından ayrıştığı saptanmıştır. Bu farklılıkların altındaki olası nedenler Türkiye'deki eğitim ve sosyal bağlam doğrultusunda açıklanmış ve tartışılmıştır.

Anahtar Kelimeler: Cinsiyet temsili, cinsiyet rolleri, ders kitapları, meslek ve sıfat gösterimleri

* Araș. Gör., Anadolu Üniversitesi, Eğitim Fakültesi, Yabancı Diller Eğitimi Bölümü, İngilizce Öğretmenliği Programi,sibelsogut@anadolu.edu.tr 


\section{INTRODUCTION}

The gender representations in English Language Teaching (ELT) materials have been the subject of inquiry in research studies because not only learners but also teachers are exposed to the ideological content, gender-biased representations, and stereotypical features of these materials. Undoubtedly, these stereotypical features inevitably have an effect on both learners' and teachers' values, behaviours, world-views, and mindsets. Learners are exposed to such contents through the topics, pictures, example sentences, reading passages, discussion questions, and many activities included in the books (Arıkan, 2005). More specifically, the content of the coursebooks "will always communicate at least some attitudes, ideas, beliefs or values related to concepts, at the macro level, such as individualism, egalitarianism, universalism and so forth" (Hurst, 2014 , p. 55). These values may lead to stereotypical thinking among students towards society and cause deteriorations in "hatred, intolerance, or belittling of others, resulting in the erosion in societal peace and solidarity" (Arıkan, 2005, p. 8). The existence of gender bias and sexist language in instructional materials has been proved to influence learners negatively. According to Thomas (2004), sexist language "represents women and men unequally, as if members of one sex were somehow less completely human, less complex, and had fewer rights than members of the other sex" (p. 76). An intriguing example for the negative effect of this case is Schultze's (1974) study: s/he indicates that the omission of females and feminine examples in a Russian textbook is the source of the student's failure to recognize feminine endings of past-tense verbs. Gender representations in coursebooks also affect learners in some other ways. More specifically, gender representation has three potential effects on the learners (Sunderland, 1992). Accordingly, cognitive and communicative empowerment for female learners is not possible when the female characters are attributed to restricted social, behavioral, and linguistic roles. Secondly, when female learners are attributed relatively few and limited roles, they are "offended, alienated, or made to feel marginalized by this and subsequently demotivated" and thirdly, "models of language may give the whole class a model of conversational discourse characterized by "male firstness"" (Sunderland, 1992, p. 85). Thus, a balanced representation of female and male roles has crucial importance. The source of this importance also originates from the fact that coursebooks play a crucial role in "determining students' perceptions of female and male roles in society" (Hall, 2014 , p. 235). In the same vein, the content of instructional materials is found to affect students' attitudes and dispositions towards themselves, others, and society (Ndura, 2004).

\subsection{Aim of the Study}

The aim of the current study is to investigate the gender representations in high school ELT coursebooks (i.e., B1.1, B1.2, B2.1, B2.2 levels) in terms of jobs and adjectives attributed to male and female characters. In the light of this aim, the following research questions are addressed within the scope of the study:

1- How are the gender roles represented in high school ELT coursebooks in terms of job and adjective attributions?

2- Is the distribution of female and male characters balanced in terms of job and adjective attributions? 


\subsection{Significance of the Study}

The results of the previous research studies in the relevant literature indicate that female characters are attributed a narrow range and a limited number of roles whereas men occupy more number and variety of roles in both visual and written elements of the coursebooks. Considering the crucial roles of the coursebooks in having the potential to transmit the stereotypical thinking in students' minds, the present study aims to shed light on the distribution of the gender roles between female and male characters in the coursebooks. One of the underlying motives in conducting the current study is that scholars argue that gender representation is an important issue in the design of instructional materials and welcome the efforts of other scholars and educators to examine a variety of materials and share their findings to continue this discussion (Rifkin, 1998). This study aiming to examine gender roles the high school ELT coursebooks, which are published by Turkish Ministry of National Education, is significant as gender bias and imbalance presented in coursebooks have the potential to affect the target audience negatively. The results of the present study are also believed to shed light on the regulations and revisions to be made in these coursebooks.

\section{REVIEW OF LITERATURE}

The content of ELT coursebooks have been widely examined from different perspectives such as their modes of representation in terms of ideology (e.g., Copley, 2017), cultural content of foreign language teaching materials (e.g., Skopinskaja, 2003), illustrations in ELT coursebooks (e.g., Galván, 2018), presentation of animals (e.g., Jacobs, Jiexin \& Michael, 2016). Gender representations in coursebooks have also been one of these most widely investigated aspects in the relevant literature (Bulut, 2008; Cunningsworth, 1995; Demira \& Yavuz, 2017; Diktaş, 2011; Holmqvist \& Gjörup, 2006; Lee \& Collins, 2006; Sakita, 1995; Sivasligil, 2006; Skliar, 2007; Söylemez, 2010; Y1lmaz, 2012). Gender representations in coursebooks has been investigated in different educational settings such as Japanese (e.g., Sakita, 1995), Iranian (e.g., Hall, 2014), Swedish (e.g., Holmqvist \& Gjörup, 2006), Jordanian (e.g., Hamdan, 2010); Hong Kong (e.g., Lee \&Collins, 2006), Turkish (e.g., Arıkan, 2005; Bilgin, 2013; Bulut, 2008; Demira \& Yavuz, 2017; Diktaş, 2011; Söylemez, 2010; Y1lmaz, 2012), Singapore (e.g., Gupta \& Yin, 1990), Russian (e.g., Schultze, 1974), Tanzanian (e.g., Mkucku, 2004) settings. One of the common points in the aforementioned research studies is that female characters in textbooks are attributed mostly domestic roles whereas male characters are found to perform prestigious and more variety of jobs. The imbalance has been found between female and male characters in terms of the amount of speech given to characters, and in role-presentation and the importance of male characters increases as the level of the reader rises (Gupta \&Yin, 1990). In addition to the aforementioned categorization on the presence of gender bias, there has been studies in the literature providing evidence for the presence of gender-biased content in the coursebooks. One of the comprehensive analysis provided on the types of gender bias presented in EFL textbooks argues that there are three main senses on the bias against women: 'exclusion' (males are over presented), 'subordination and distortion' (men tended to occupy both more powerful and a greater range of occupational roles than did women), and 'degradation' (women tended to be stereotypically emotional) (Sunderland, 2000, p. 151). 
In the relevant literature, there have been research studies conducted in different educational settings. To start with, in the Turkish educational setting, Y1lmaz (2012) compared the first editions and revised versions of English language coursebooks in order to examine whether writers and publishers take the gender issue into consideration. As a result of her analyses, she found out that female and male characters in the first editions of the coursebooks were closer to the stereotypical representations. There found to be a more balanced gender representation in the last editions of these coursebooks. Another study conducted in Turkish setting examined the $6^{\text {th }}, 7^{\text {th }}$ and $8^{\text {th }}$ grade English coursebooks published by the Turkish Ministry of National Education in order to reveal any existence of gender discrimination (Sivasligil, 2006). It was revealed that females were underrepresented in terms of frequency of appearance, amount of talk, representations in family roles and other social and occupational roles, distribution of household responsibilities and spare time and leisure activities in most cases. In a more recent study, Söylemez (2010) investigated adjectives attributed to female and male characters in coursebooks Face2Face and English File in terms of their reading text. The results of the study indicated that adjectives used for females modify more extreme and exaggerated feelings such as being shocked instead of surprised or feeling fantastic instead of well and it was also found out that adjectives such as famous and rich are attributed to the male characters in these coursebooks. In a more recent study, Demira and Yavuz (2017) examined gender representations in an ELT coursebook series, Yes You Can, in terms of visibility in the illustrations, occupational groupings, domestic roles, household and out of home responsibilities, associated activities and sports, amount of talk, the dispersion of interlocutors, firstness, gender actually focused on in writings. They found out that with regard to the occupations assigned to males and females, there are both positive and negative associations in the coursebook series.

In addition to the research studies conducted in Turkish context, there are research studies conducted in different educational settings. For instance, in the Japanese setting, Sakita (1995) investigated ten EFL textbooks in junior and senior high schools. S/he found out that males were committed to have occupations such as mountaineer, reporter, engineer, writer, basketball player, artist, clerk in a big office, lecturer, physician, doctor, sailor, colonel, priest and carpenter while female characters were attributed to a more limited number of roles such as student, maid, actress, mother and ballet dancer. In the Swedish setting, Holmqvist and Gjörup (2006) examined six EFL textbooks used in secondary schools. They found out that majority of the occupations were held by men whereas women were described either without an occupation or with a stereotypical one such as teacher, nurse, housewife, student. In Hong Kong setting, Lee and Collins (2006) aimed to find out the changes in the gender representation in secondary English textbooks over the past decade. Based on his comparative analysis, he found out that there was not any change over time: women continue to have traditional roles such as secretary, maid and typist. In addition to the aforementioned explicit signs of gender bias, there has been studies conducted to figure out the implicit messages for gender roles (e.g., Cunningsworth, 1995). He indicated that in spite of the fact that women and men are represented equally, there are a number of unbalanced points such as the outnumber of famous men in history compared to women.

There is also an international concern about gender representation, and this issue was also reported in Global Education Monitoring Report (Benavot \& Jere, 2016). In this report, scholars argue that in lines of text, proportions of named characters, mentions in titles, 
citations in indexes - girls and women are under-represented in textbooks and curricula. A number of examples from different countries (i.e., Pakistan, Iran, Australia, Sweden, Jordan, India, Georgia, China) are provided and the common problem addressed is the negative portrayal and underrepresentation in textbooks.

Considering the above-cited studies and the global problem related to gender bias, the present study is significant in that it focuses on adjectives modifying female and male characters and on jobs attributed to these characters in high school ELT coursebooks published by Turkish Ministry of National Education. Considering the fact that coursebooks are the main teaching sources used by English language teachers and main language learning sources Turkish students are exposed to, analysis of these materials has crucial importance to unveil the gender representations. Last but not least, providing implications for this problem is significant in order to raise awareness about the existence of gender-biased and sexist language in coursebook materials.

\section{METHODOLOGY}

This is a descriptive research study; content analysis method is used for coding and categorizing the data, and the categories set for content analysis are 'jobs' and 'adjectives' attributed to female and male characters in the coursebooks. More specifically, a qualitative content analysis is used in order to identify job and adjective attributions. In this regard, qualitative content analysis is defined as "a research method for the subjective interpretation of the content of text data through the systematic classification process of coding and identifying themes or patterns" (Hsieh \& Shannon, 2005 , p. 1278). The reason for using qualitative content analysis is that it goes beyond identifying frequency counts and it helps to classify text into categories representing similar meanings (Weber, 1990). The coursebooks used as the data of this research are all B level ELT coursebooks including the workbooks published by the Turkish Ministry of National Education. The name of the books is Yes, You Can and the grades of 9, 10, 11 and 12 use these coursebooks at the state high schools in Turkey. The themes of the coursebooks are 'communication, science, and technology, education, tourism, emotions, art, jobs, design, nature, and environment'. The coursebooks of these levels are chosen within the scope of this study as the target users of the books are teenagers and these books are compulsory at state high schools in Turkey. In most schools, students' main source for learning English is the book provided by Turkish Ministry of National Education, and they are not provided with additional materials apart from the coursebook. In this respect, according to Lee and Collins (2006), "learners, who generally attach great credibility and authority to educational materials, tend to absorb and assimilate the materials in minute detail without comment and to be susceptible to their influence" (p. 128). Considering the target audience of the coursebooks, the learners are early adolescents in the period of identity development, and this is also a period when they receive their earliest education about norms, culture, and the world around them, they are uncertain about their identities and future plans. (Hall, 2014). Undoubtedly, gendered messages have the potential to influence the development of students' attitudes at an impressionable age (Lee \& Collins, 2006).

In the data analysis procedure, a frequency count was done to determine the number of roles female and male characters that are attributed. In this respect, the frequencies of jobs and adjective attributions of male and female characters were determined by 
counting the tokens. Proper nouns and personal pronouns (i.e., she and he) are also counted, and the occurrences in reading passages, conversations, exercises are all involved in the analyses. Female and male attributions are counted by taking into account every time the character appeared in any sentence of the unit. In the second phase of the analysis, jobs and adjectives attributed to female and male characters are classified and compared. The adjectives are classified based on Dixon's (1982) classification, and the most salient category is presented. Dixon (1982) proposed seven semantic types which make up the word class adjective: dimension (big, large, little, small, short, etc.), physical property (hard, soft, heavy, light, cold, sweet, etc.), colour (black, white, red, etc.), human propensity (jealous, happy, clever, proud, generous, cruel, etc.), age (new, old, etc.), value (good, bad, excellent, delicious, etc.), speed (fast, quick, slow, etc.). A limitation of the study is that the listening texts are not involved in the study and linguistic features in reading texts, sample sentences, exercises are analysed within the scope of the study. One of the coursebooks was analysed by another researcher, the results were cross-checked, and differences were compromised. Cohen's Kappa value calculated for inter-rater reliability was .93 , which means two researchers reached a near perfect agreement in deciding on the categories.

\section{RESULTS OF THE STUDY}

The results of the study show that there are 102 occupations represented in all grades of the English coursebooks in total. Female characters are found to perform 32 of them whereas male characters are found to perform twice as much, which happen to be 70 tokens as shown in the table below. The most distinct attribution number across coursebook levels exist at B1.1 and B2.1 levels. In summary, male characters are attributed greater number of jobs compared to female characters at all coursebook levels. In addition to under-presentation of female characters, there are fluctuations of the representation of female and male characters among the proficiency levels. Namely, a number of adjectives and jobs attributed to female characters at B1.1 level is higher than other levels whereas this number is the lowest at B2.2 level.

Table 1.

Frequencies of Jobs and Adjectives Attributed to Each Gender Across Coursebooks

\begin{tabular}{lllllllll}
\hline Level & \multicolumn{1}{l}{ Female } & \multicolumn{7}{l}{ Male } \\
\hline & Jobs & \multicolumn{2}{l}{ Adjectives } & \multicolumn{2}{l}{ Jobs } & \multicolumn{2}{l}{ Adjectives } \\
\hline B1.1 & tokens & \% & tokens & \% & tokens \% & tokens & \% \\
B1.2 & 12 & 37.5 & 24 & 44 & 20 & 28.5 & 29 & 36.7 \\
B2.1 & 3 & 9.3 & 9 & 16.6 & 12 & 17.1 & 20 & 25.3 \\
B2.2 & 8 & 25 & 10 & 18.5 & 23 & 32.8 & 20 & 25.3 \\
TOTAL & 9 & 28.1 & 11 & 20.3 & 15 & 21.4 & 10 & 12.6 \\
\hline
\end{tabular}

Considering the distribution of jobs and adjectives attributed to females and males, in this part of the study, a detailed analysis of which jobs and adjectives are attributed to each gender are examined. The results show that female characters are attributed more domestic and indoor jobs such as nurse, teacher, carpet weaver, waitress, housekeeper whereas male characters occupy more prestigious jobs such as astronomer, writer, mountain climber, professor, career builder, researcher, ambassador, psychologist, and so on. In spite of some similar jobs (i.e., teacher, doctor, architect) attributed to both 
genders, female and male characters in the coursebooks differ from each other in terms of both the number and variety of jobs attributed to them as seen in the table below:

Table 2.

Jobs Attributed to Female and Male Characters

\begin{tabular}{|c|c|c|c|c|}
\hline & B1.1 & B1.2 & B2.1 & B2.2 \\
\hline Female & $\begin{array}{l}\text { doctor, pop star, } \\
\text { bookkeeper, } \\
\text { candle store } \\
\text { clerk, } \\
\text { professional } \\
\text { dancer, student, } \\
\text { ambassador, } \\
\text { poet, journalist } \\
\text { (X2), nurse, } \\
\text { teacher }\end{array}$ & $\begin{array}{l}\text { swimmer, } \\
\text { teacher, student }\end{array}$ & $\begin{array}{l}\text { athlete, } \\
\text { ballroom } \\
\text { dancer, waitress } \\
\text { (X2), worker, } \\
\text { teacher, doctor, } \\
\text { architect }\end{array}$ & $\begin{array}{l}\text { nurse, } \\
\text { housekeeper, } \\
\text { artist, } \\
\text { newspaper } \\
\text { delivery girl, } \\
\text { carpet weaver, } \\
\text { coffee picker, } \\
\text { social } \\
\text { psychologist, } \\
\text { doctor, architect }\end{array}$ \\
\hline Male & $\begin{array}{l}\text { mountain } \\
\text { climber, writer, } \\
\text { photographer, } \\
\text { documentary } \\
\text { film producer, } \\
\text { motivational } \\
\text { speaker, } \\
\text { sportsman, } \\
\text { climber, co- } \\
\text { founder, } \\
\text { president (of } \\
\text { AKUT), actor, } \\
\text { writer, taxi } \\
\text { driver, } \\
\text { businessman, } \\
\text { hacker, waiter, } \\
\text { astronomer, } \\
\text { cook, teacher } \\
\text { (X4) }\end{array}$ & $\begin{array}{l}\text { writer (X2), } \\
\text { psychologist } \\
(\mathrm{X}) \text {, career } \\
\text { builder, doctor, } \\
\text { architect, } \\
\text { entertainer, } \\
\text { ambassador, } \\
\text { executive } \\
\text { director, } \\
\text { general, teacher }\end{array}$ & $\begin{array}{l}\text { businessman, } \\
\text { yard worker, } \\
\text { boxer, } \\
\text { billionaire (X3), } \\
\text { poet, leader, } \\
\text { statesman, } \\
\text { commander, } \\
\text { service } \\
\text { specialist, } \\
\text { registerer, } \\
\text { technology } \\
\text { staff, captain, } \\
\text { movie star, } \\
\text { teacher, } \\
\text { professor (X2), } \\
\text { doctor (X2), } \\
\text { salesman, ballet } \\
\text { dancer, } \\
\text { congressman }\end{array}$ & $\begin{array}{l}\text { teacher, } \\
\text { executive } \\
\text { chairman, group } \\
\text { CEO, } \\
\text { researcher, } \\
\text { biologist, } \\
\text { sculptor (X2), } \\
\text { senior } \\
\text { executive, } \\
\text { executive } \\
\text { director, miner, } \\
\text { sports } \\
\text { sociologist }\end{array}$ \\
\hline
\end{tabular}

Note: the use of $\mathrm{X}$ refers to 'times'

As far as the results of the study are concerned in terms of the adjectives attributed to both genders, adjectives expressing human propensity are the most salient ones based on Dixon's (1982) adjective classification. These adjectives are mostly attributed to female characters, and they have negative connotations especially at the B1.1 level, and they mostly express negative feelings such as being worried, angry, unhappy and negative personality traits such as anti-social, alone, isolated, rude as shown in the table below. 
Table 3.

Adjectives Attributed to Female and Male Characters

\begin{tabular}{|c|c|c|c|c|}
\hline & B1.1 & B1.2 & B2.1 & B2.2 \\
\hline Female & $\begin{array}{l}\text { unhappy, } \\
\text { isolated, alone, } \\
\text { not happy, anti- } \\
\text { social, hungry, } \\
\text { tired, pretty, } \\
\text { stressed, angry } \\
\text { (X2), stressful } \\
\text { (X2), } \\
\text { formidable, } \\
\text { little, interested, } \\
\text { bored, } \\
\text { thoughtful, } \\
\text { defensive, } \\
\text { disgusted, } \\
\text { happy, worried, } \\
\text { sad, surprised }\end{array}$ & $\begin{array}{l}\text { talented, } \\
\text { successful, } \\
\text { curious, } \\
\text { determined, } \\
\text { decisive, } \\
\text { optimistic, } \\
\text { extrovert, little, } \\
\text { clever }\end{array}$ & $\begin{array}{l}\text { inexperienced, } \\
\text { famous, bossy, } \\
\text { understanding, } \\
\text { tolerable, } \\
\text { exquisite, } \\
\text { jealous, nice, } \\
\text { kind, worried }\end{array}$ & $\begin{array}{l}\text { thin, } \\
\text { disappointed, } \\
\text { rude, } \\
\text { disrespectful, } \\
\text { alone, } \\
\text { hardworking, } \\
\text { lazy (the } \\
\text { laziest), old, } \\
\text { thoughtful, } \\
\text { good, worried }\end{array}$ \\
\hline Male & $\begin{array}{l}\text { famous (X2), } \\
\text { healthy, } \\
\text { incredible, tall, } \\
\text { nervous, poor, } \\
\text { terrible, } \\
\text { confused, } \\
\text { faithful, } \\
\text { trustworthy, } \\
\text { honouring, } \\
\text { excellent, } \\
\text { respective, } \\
\text { sympathetic, } \\
\text { brilliant, } \\
\text { successful, } \\
\text { hardworking, } \\
\text { angry (X2), } \\
\text { generous, old, } \\
\text { (most)careful, } \\
\text { the angriest, the } \\
\text { wisest, the } \\
\text { gentlest, } \\
\text { (most)generous, } \\
\text { happy }\end{array}$ & $\begin{array}{l}\text { famous(X3), } \\
\text { sociable, } \\
\text { enthusiastic, } \\
\text { indecisive, } \\
\text { pessimistic, } \\
\text { introvert, } \\
\text { anxious, } \\
\text { overweight, } \\
\text { hopeless, } \\
\text { talented, young } \\
\text { (X3), clever, } \\
\text { talented, } \\
\text { handsome, } \\
\text { regretful, } \\
\text { successful }\end{array}$ & $\begin{array}{l}\text { young, } \\
\text { frightening, } \\
\text { unemployed, } \\
\text { successful, } \\
\text { peerless, } \\
\text { powerful, great, } \\
\text { legendary, } \\
\text { strong, } \\
\text { persuasive, } \\
\text { realistic, patriot, } \\
\text { intelligent, } \\
\text { warm, sincere, } \\
\text { honest, loyal, } \\
\text { coward, shy, } \\
\text { handsome }\end{array}$ & $\begin{array}{l}\text { young, } \\
\text { frightening, } \\
\text { unemployed, } \\
\text { successful, } \\
\text { peerless, } \\
\text { powerful, great, } \\
\text { legendary, } \\
\text { strong, } \\
\text { persuasive, } \\
\text { realistic, patriot, } \\
\text { intelligent, } \\
\text { warm, sincere, } \\
\text { honest, loyal, } \\
\text { coward, shy, } \\
\text { handsome (X2), } \\
\text { friendly, } \\
\text { surprised, } \\
\text { thoughtful, } \\
\text { experienced, } \\
\text { patient, well } \\
\text { organized, } \\
\text { hardworking, } \\
\text { best-known, } \\
\text { tired }\end{array}$ \\
\hline
\end{tabular}

There are a number of similar adjectives attributed to both genders such as famous, thoughtful, successful. However, the majority of the adjectives with negative connotations are found to modify personal traits of female characters. 


\section{DISCUSSION AND CONCLUSION}

The results of the study show that there found to be 102 occurrences of jobs represented in all grades of the English coursebooks in total. However,, there found to be an imbalance in the distribution of these jobs. Namely, it was found out that females are shown performing 32 of there, whereas males are shown performing 70 of them. There are salient differences and fluctuations in the representation of female and male characters among the proficiency levels. Namely, a number of adjectives and jobs attributed to female characters at B1.1 level is higher than other levels whereas this number is the lowest at B2.2 level. When these jobs are analysed in detail, it is clearly seen that female characters are found to perform indoor jobs, and traditional ones such as teacher, nurse, dancer, waitress, housekeeper, carpet weaver whereas males are found to perform mostly outdoor jobs and high prestigious ones such as researcher, businessman, professor, astronomer, architect, executive director, general, climber, photographer. In addition to the aforementioned finding, females are found to be attributed less number of adjectives compared to males, and many of the adjectives attributed to females have negative connotations such as anti-social, alone, stressful, worried, defensive, angry, inexperienced, jealous, disrespectful. while males are mostly attributed to adjectives with positive connotations such as loyal, legendary, intelligent, well-organized, respective, faithful, successful, talented, sociable, famous. The explanation of this overview in coursebooks may be that gender role orientations of females and males influenced by the social norms and values. Namely, there might be gender differences in the fundamental value orientations, such as the relative importance attached to individual versus collective well-being, instrumental versus expressive social relations, and a materially-oriented versus reflective life (Beutel \& Marini, 1995; Gilligan, 1982). Apart from the values of the society, distribution of labor force and employment rates among females and males in Turkey have also an inevitable effect and reflection on the roles attributed to both genders. More specifically, according to the report by Turkish Statistics Institute in 2017, labor force for women is 31,5\% whereas it is $71,6 \%$ for men in Turkey. As far as the employment rate is concerned, it is $27,5 \%$ for women while it is $65 \%$ for men (Turkish Statistical Institute, 2017). Undoubtedly, these percentages and social facts shape values, viewpoints, mindsets of the members of the society. The attribution of a narrower range of roles to females and overpresentation of jobs to male characters may originate from the aforementioned social facts and statistics. Another possible reason is that the centralist attitude prevails in the production and evaluation of local English coursebooks in Turkish EFL setting (Şimşek \& Dündar, 2017). In addition to the aforementioned reason, there are a number of common trends both traditional and modern societies share: "men are supposed to be more concerned with achievements outside the home ... and women are supposed to be more concerned with taking care of the home' (Hofstede, 2003, p. 80-1).

The results of the current study are in parallel with Demira and Yavuz's (2017) study in that men were associated with significantly more careers than women in Yes You Can. The findings of the present study show a reverse case in terms of the distribution of jobs and adjectives, and the results do not correspond as they claim that the coursebook embodies a very elaborately distributed, gender-inclusive language and representations. The reason for this different interpretation may be the scope of the research studies; their scope is wider, and the main elements of their study were visibility in the illustrations, occupational groupings, domestic roles, household and out of home responsibilities, 
associated activities and sports, amount of talk, the dispersion of interlocutors, firstness, gender actually focused on in writings.

Unfortunately, the presence of gender bias and sexist language in the coursebook materials have the potential to empower and trigger stereotypical thinking in students' mindsets. As Graci (1992) notes, "pedagogy inevitably involves the transmission, exchange, and initiation of ideas. When subtle or blatant sexism is present in the curriculum, that information is then conveyed to the learners" (p. 2). Thus, focusing on gender representations in the coursebooks is believed to shed light on the regulations and revisions to be made in these coursebooks. All in all, the coursebooks analysed in this study are recommended to adopt a more balanced approach in terms of the jobs and adjectives attributed to female and male characters. Additionally, curriculum designers and material developers should consider the guidelines of gender-fair material development as a discriminatory content may lead female students to restrict their social, behavioral, and linguistic roles (Amini \& Birjandi, 2012). In parallel to the aforementioned negative effects, a gender-biased content has the potential to lead students to stereotypical thinking as "schools are places in which teachers, course books, classroom materials, activities, and attitudes of all members of a given school or classroom contribute to the cognitive and emotional formation of students through knowledge-based and value-laden practices, an infinite number of messages or values are passed on to students" (Arıkan, 2005, p. 38). In this respect, Özdoğru, Aksoy, Erdoğan, and Gök (2006) indicates that educational systems help their students to develop and internalize these socially accepted gender roles through their instructional materials. Undoubtedly, coursebooks with an inclusive content have the potential to counter the prejudices students bring with them into the classroom (Opoku-Amankwa, 2010). Thus, there should be more interest in terms of equal gender representation and in the prevention of sexist language in the coursebooks. In this respect, Rifkin (1998) suggested that one of the criteria for deciding appropriacy of instructional materials for the classroom use should be gender equity.

Textbooks are used by teachers as a core means of teaching in $70-95 \%$ of classroom time and discriminatory gender norms and practices conveyed in and through textbooks can lower their engagement in the classroom (Benavot \& Marini, 2016). Considering the results of the present study, the main suggestion is to raise awareness about the genderbiased content of coursebooks among coursebook writers, planners, teachers, policy makers, parents, and students. Another significant suggestion is to revise the coursebooks and dissolve gender-biased content existing in coursebooks. Both teachers and parents should be aware of sexist language and provide sufficient support in order to prevent the potential sparks of stereotypes among learners. In addition, teacher educators should raise awareness of prospective teachers about the existence of gender-biased and sexist language in coursebook materials. This awareness may be promoted by bringing examples to the classroom, analysing the gender-biased content of coursebooks and providing alternative solutions to prevent potential threats to this issue. As far as the research studies are concerned, the extent to which students are critical about the contents of the coursebooks is the neglected and less searched area (Copley, 2017). Thus, future research studies may involve both a critical analysis of gender representation and the learners' evaluation of the content of the coursebooks. By this way, proposing possible solutions and revisions to prevent the sexist language and gender bias problem in coursebooks would be possible and realistic. 


\section{REFERENCES}

Amini, M., \& Birjandi, P. (2012). Gender bias in the Iranian high school EFL textbooks. English Language Teaching, 5(2), 134-147.

Arıkan, A. (2005). Age, gender and social class in ELT coursebooks: A critical study. Hacettepe Üniversitesi Eğitim Fakültesi Dergisi, 28, 29-38.

Benavot, A. \& Jere, C. (2016). Gender bias in rife in textbooks: Global education monitoring report (GEM). Retrieved from https://gemreportunesco.wordpress.com/2016/03/08/gender-bias-is-rife-intextbooks/ . University of East Anglia, United Kingdom.

Beutel, A. M., \& Marini, M. M. (1995). Gender and values. American Sociological Review, 60(3), 436-448.

Bilgin, H. (2013). Gender representations in the 6th, 7th and 8th grade ELT coursebooks published by the Turkish Ministry of National Education. MA Thesis: Bilkent University, Ankara.

Bulut, M. (2008). Socially responsible teaching in ELT: An evaluation of coursebooks on ethnicity, gender, and disability. MA: Hacettepe University.

Copley, K. (2017). Neoliberalism and ELT coursebook content. Critical Inquiry in Language Studies, 1-20.

Cunningsworth, A. (1995). Choosing your coursebook. Oxford: Heinemann.

Demira, Y., \& Yavuz, M. (2017). Do ELT coursebooks still suffer from gender inequalities? A case study from Turkey. Journal of Language and Linguistic Studies, 13(1), 103-122.

Diktaş, M. (2011). Gender Representation in EFL Coursebooks. 2nd International Conference on New Trends in Education and Their Implications (27-29 April, 2011) Antalya-Turkey.

Dixon, R. M. W. (1982). Where have all the adjectives gone? Berlin-Amsterdam-New York: Mouton.

Galván, S. G. (2018). ELT Coursebook Illustrations: A Critical Multimodal Discourse Analysis in Mexico. World Academy of Science, Engineering and Technology, International Journal of Cognitive and Language Sciences, 12(2).

Gilligan, C. (1982). In a different voice. Cambridge, MA: Harvard University Press.

Graci, J. P. (1992). Gender role portrayal in college level elementary Spanish language textbooks. Ann Arbor, MI: University Microfilms, International.

Gupta, A. F., \& Yin, A. L. S. (1990). Gender representation in English language textbooks used in the Singapore primary schools 1. Language and education, $4(1), 29-50$.

Hall, M. (2014). Gender representation in current EFL textbooks in Iranian secondary schools. Journal of Language Teaching and Research, 5(2), 253-261. 
Hamdan, S. (2010). English-language textbooks reflect gender bias: A case study in Jordan. Advances in Gender and Education, 2, 22-26.

Hofstede, G. (2003). Culture's consequences: Comparing values, behaviors, institutions and organizations across nations. Sage publications.

Holmqvist, P., \& Gjörup, L. (2006). The representation of gender and gender roles in English textbooks. Malmö University Electronic Publication. Malo Hogskola, Lararutbildningen.

Hsieh, H. F., \& Shannon, S. E. (2005). Three approaches to qualitative content analysis. Qualitative Health Research, 15(9), 1277-1288.

Hurst, N. R. (2014). Visual representations in Portuguese produced English language teaching coursebooks. Linguarum Arena. Revista de Estudos em Didática de Linguas da Universidade do Porto, 5.

Jacobs, G. M., Jiexin, T., \& Michael, J. J. (2016). The presentation of animals in English as an additional language coursebooks. Language and Ecology, 1-9.

Lee, J. F., \& Collins, P. (2006). Gender representation in Hong Kong English textbooks. Linguistics and Education, 1, 23-36.

Mkuchu, S. G. V. (2004). Gender roles in textbooks as a function of hidden curriculum in Tanzania primary schools. PhD Thesis, University of South Africa.

Ndura, E. (2004). ESL and cultural bias: An analysis of elementary through high school textbooks in the Western United States of America. Language, Culture and Curriculum, 17(2), 143-153.

Opoku-Amankwa, K. (2010). What happens to textbooks in the classroom? Pupils' access to literacy in an urban primary school in Ghana. Pedagogy, Culture \& Society, 18(2), 159-172.

Özdoğru, A.A, Aksoy, G., Erdoğan, N. \& Gök, F. (2006). Content Analysis for Gender Bias in Turkish Elementary School Textbooks. Paper presented at the 18th Annual Conference on Ethnographic and Qualitative Research in Education (June 9 and 10). Dayton, $\mathrm{OH}$.

Rifkin, B. (1998). Gender representation in foreign language textbooks: A case study of textbooks of Russian. The Modern Language Journal, 82(2), 217-236.

Sakita, T. I. (1995). Sexism in Japanese English education: A survey of EFL texts. Women and Language, 13(2), 5.

Schultze, S. (1974). Sexism in Russian grammars. Russian Literature Triquarterly, 9, 571-574.

Sivasligil, P. (2006). Gender ideology in 6th, 7th and 8th grade coursebooks published by the Turkish Ministry of Education. MA Thesis, Çukurova University, Adana, Turkey.

Skliar, O. (2007). Gender representations and gender bias in ELT textbooks published in the Middle East: A case study of ELT textbooks published in Turkey and Iran. MA thesis, Middle East Technical University, Ankara, Turkey. 
Skopinskaja, L. (2003). The role of culture in foreign language teaching materials: An evaluation from an intercultural perspective. In I. Lazar (Eds.)., Incorporating intercultural communicative competence in language teacher education (pp. 39-68). Bachernegg, Kapfenberg.

Söylemez, A. S. (2010). A study on how social gender identity is constructed in EFL coursebooks. Procedia-Social and Behavioral Sciences, 9, 747-752.

Sunderland, J. (1992). Gender in the EFL classroom. Elt Journal, 46(1), 81-91.

Sunderland, J. (2000). New understandings of gender and language classroom research: Texts, teacher talk and student talk. Language Teaching Research, 4(2), 149173.

Şimşek, M. R., \& Dündar, E. (2017). Investigating EFL coursebook research in Turkey: Trends in graduate theses of the 2001-2013 Period. Educational Sciences: Theory \& Practice, 17(3), 969-1014.

Türkiye İstatistik Kurumu (2017). Istatistiklerle kadın, 2016 (Rapor No: 24643), Retrieved from http://www.tuik.gov.tr/PreHaberBultenleri.do?id=24643. Ankara, Türkiye.

Thomas, L. (2004). Language, society and power: An introduction (2nd ed). Ishtla Singh \& Jean Stilwell Peccei. London and New York: Routledge.

Weber, R. P. (1990). Basic content analysis. Beverly Hills, CA: Sage.

Yilmaz, E. (2012). Gender representations in ELT coursebooks: A comparative study. MA: Middle East Technical University.

Coursebooks

1- Yes You Can (Student's Book) B1.1. (Yayınevi: MEB)

2- Yes You Can (Student's Book) B1.2. (Yayınevi: MEB)

3- Yes You Can (Student's Book) B2.1. (Yayınevi: MEB)

4- Yes You Can (Student's Book) B2.2. (Yayınevi: MEB) 


\section{GENIŞ ÖZET}

\section{Giriş}

İngilizce ders kitaplarındaki cinsiyet gösterimleri hem öğrencilerin hem de öğretmenlerin kitapların ideolojik içeriğine, cinsiyet yanlısı gösterimlerine ve basma kalıp özelliklerine maruz kalmalarından dolayı alanyazında bilimsel araştırmalara konu olmuştur. Şüphesiz, bu özelliklerin hem öğrencilerin hem de öğretmenlerin değer yargılarını, dünya görüşlerini, zihniyetlerini etkilemesi kaçınılmazdır. Öğrenciler cinsiyet yanlı bu gösterimlere ders kitapları içerisinde yer alan başlıklar, resimler, örnek cümleler, okuma metinleri, tartışma soruları ve diğer etkinlikler aracılığıyla maruz kalırlar (Arıkan, 2005). Ders kitaplarının içeriklerinin "genel düzeyde bireysellik, eşitlikçilik, evrenselcilik gibi kavramlarla ilgili her zaman belli tutumları, düşünceleri, inançları veya değerleri ileteceği” (Hurst, 2014, s. 55) vurgulanmıştır. Ayrıca, ders kitaplarındaki cinsiyet yanlı içeriğin ve cinsiyetçi söylemin öğrencileri olumsuz yönde etkilediği saptanmıştır. Örneğin, Rusça ders kitaplarında kadın karakterlerin ve örneklerinin yer almaması öğrencilerin eylemlerdeki geçmiş zaman eklerini ayırt edememelerinin kaynağı olduğu saptanmıştır (Schultze, 1974). Bu yüzden, kadın ve erkek rollerinin dengeli dağılımı oldukça önemlidir. Ders kitaplarının öğrencilerin toplumdaki kadın ve erkek rollerine ilişkin algılarını belirlemede önemli bir role sahiptir (Hall, 2004). Ders malzemelerinin içeriği öğrencilerin kendilerine, diğer insanlara ve topluma karşı tutumlarını etkilemektedir (Ndura, 2004). Ders kitaplarının öğrencilerin zihninde basma kalıp düşüncelere olası etkileri göz önünde bulundurulduğunda, bu çalışma kadın ve erkek rollerinin dağılımına ilişkin ışık tutmayı amaçlamaktadır. Bu bağlamda, çalışmanın amacı lise düzeyinde okutulan İngilizce ders kitaplarında (B1.1, B1.2, B2.1, B2.2 seviyelerde) cinsiyet gösterimlerini kadın ve erkek karakterlere yüklenen meslek ve sıfatlar bakımından incelemektir. Bu amaç ışığında yönlendirilen araştırma soruları şunlardır:

1- İngilizce ders kitaplarındaki cinsiyet rollerinin meslek ve sıfat gösterimleri açısından görünümleri nasıldır?

2- Kadın ve erkek karakterlere atfedilen meslek ve sıfat gösterimleri benzeşik midir?

\section{Yöntem}

$\mathrm{Bu}$ çalışma betimsel bir araştırmadır: veriyi işaretlemek ve sınıflandırmak için içerik analizi yöntemi kullanılmıştır ve içerik analizi için kullanılan kategoriler ders kitaplarında kadın ve erkek karakterlere yüklenen 'meslek' ve 'sıfat'lardır. Başka bir deyişle, meslek ve sıfat gösterimlerini saptamak amacıyla nitel içerik analiz yöntemi kullanılmıştır. Bu bağlamda, nitel içerik analizi "metinlerden oluşan bir veri setinin temalar ve örüntülerin sistematik olarak kodlanması ve sınıflandırılması yoluyla öznel bir biçimde yorumlanmasıdır" (Hsieh ve Shannon, 2005, s. 1278). Çalışma kapsamında bu yöntemin kullanılmasının sebebi; yönteminin sıklık sayımının ötesini incelemesi ve benzer anlamlardaki kategorilerin sınıflandırılmasına olanak sağlamasıdır (Weber, 1990). Çalışmanın verisini Millî Eğitim Bakanlığı tarafından yayınlanan liselerde okutulan B seviyesindeki İngilizce ders kitapları (Yes, You Can) ve çalışma kitapları oluşturmaktadır. Kitaplarda 'iletişim, bilim ve teknoloji, eğitim, turizm, duygular, sanat, meslekler, tasarım, doğa ve çevre’ gibi konular yer almaktadır. Çalışma kapsamında bu 
seviyede okutulan kitapların seçilmesinin nedeni; kitabın hedef kullanıcılarının lise öğrencileri olması ve bu kitapların Türkiye'deki devlet okullarında zorunlu olarak okutulmasıdır. Birçok devlet okulunda öğrencilerin İngilizceyi öğrenmedi temel kaynakları bu kitaplardır ve öğrencilere bunların dışında ilave ders materyali sağlanmamaktadır. Bu bağlamda, Lee ve Collins'e (2006) göre, “eğitim materyallerine büyük önem veren ve inanılırlık gösteren öğrenciler ders materyallerini üzerinde düşünmeden özümsemeye ve benimsemeye daha yatkın ve bunlardan etkilenmeye daha elverişli olurlar" (s. 128). Ders kitaplarının hedef kullanıcıları göz önünde bulundurulduğunda, öğrenciler kimlik gelişimi sürecinde olan ergen bireylerdir ve bu dönem onların etrafındaki değerleri, normları, kültürü, dünya konusunda eğitim aldıkları bir dönemdir ve bu bireyler kimlikleri ve gelecek planları konusunda karasız oldukları bir dönemdedir (Hall, 2014). Cinsiyetçi mesajların, öğrencilerin kolay etkilendikleri bu yaşta tutum gelişimini etkileme potansiyeli vardır (Lee ve Collins, 2006). Çalışmanın veri analiz sürecinde ders kitaplarındaki metinlerde kadın ve erkek cinsiyet rollerine atfedilen meslek ve sıfat gösterimlerinin sıklıkları sayılmıştır, bu bağlamda kadınlara ve erkeklere yüklenen meslek ve sıfatlar saptanmıştır. Okuma parçalarında, karşılıklı konuşmalarda, alıştırmalarda geçen özel isimler ve kişi adılları da sayılarak analize dahil edilmiştir. Veri analiz sürecinin ikinci aşamasında, kadın ve erkeklere yüklenen meslek ve sıfat gösterimleri sınıflandırılmış ve karşılaştırılmıştır. Sıfat sınıflandırması Dixon'ın (1982) sınıflamasına göre yapılmıştır ve en yaygın bulunan sınıf çalışmanın sonuçları bağlamında sunulup tartışılmıştır. Çalışmanın sınırlılığı dinleme parçalarının dahil edilmemesidir. Çalışmanın güvenirliği açısından ders kitaplarından biri başka bir araştırmacı tarafından incelenmiş̧tir; ulaşılan sonuçlar karşılaştırılmış ve farklı sonuçlar üzerinde durularak uzlaşmaya varılmıştır.

\section{Bulgular, Tartışma ve Sonuç}

Çalışmanın sonucunda, mesleklerde (ögretmen, doktor, mimar, vb.) ve sifatlarda (ünlü, düşünceli, başarılı vb.) cinsiyet dağılımlarındaki birtakım benzerliklere karşın kadın ve erkek rollerinin çalışma kapsamında incelenen bütün kitaplarda cinsiyetlere yüklenen meslek ve sıfatların hem sayı bakımından hem de çeşit bakımından ayrıştığı saptanmıştır. Çalışmanın sonucunda bütün seviyelerdeki İngilizce ders kitaplarında toplamda kadın ve erkek karakterlere toplamda 102 meslek atfedildiği; fakat bunların cinsiyetler arası dağılımında dengesizlik olduğu saptanmıştır. Kadın karakterlere bu mesleklerden 32'si, erkelere ise 70 tanesi yüklenmiştir. Kadın karakterlerin genelde ‘̈ğretmen, hemşire, dansçı, garson, temizlikçi, halı dokumacısı' gibi iç mekanlardaki ve daha geleneksel meslekleri yaparken; erkek karakterlere çoğunlukla 'araştırmacı, iş adamı, profesör, astronot, mimar, yönetici, komutan, dăgcl, fotoğrafçı' gibi daha prestijli ve diş mekan meslekleri atfedildiği belirlenmiştir. Bunun yanı sıra, kadınlara çoğunlukla 'anti-sosyal, yalnız, stresli, endişeli, öfkeli, deneyimsiz, kıskanç, saygısız' gibi negatif çağrışımları olan sıfatlar atfedilirken; erkeklere 'sadık, efsanevi, zeki, düzenli, sayglll, vefall, başarıll, yetenekli, sosyal, ünlü’ gibi pozitif çağrışımlı sıfatlar yüklenmiştir. Bu görünümün olası nedeni, kadın ve erkek cinsiyet rollerinin konumlandırılmasının toplumsal kurallardan ve değerlerden etkilenmesiyle bağlantılı olarak açıklanabilir. Toplumsal değerlerin yanı sıra, Türkiye'de kadın ve erkeklerin iş gücü ve istihdam oranı bakımından dağılımlarının cinsiyet rollerine etkisinin ve yansımasının olması kaçınılmazdır. Türkiye İstatistik Kurumu'nun 2017 raporuna göre, kadınlarda işgücü oranı \%31,5 iken erkeklerde \%71,6'dır. Bu sayısal veriler ve toplumsal gerçekler toplumdaki bireylerin değer 
yargılarını, bakış açılarını ve zihniyetini şekillendirmektedir. Bu durumun bir başka nedeni de Türkiye bağlamında ders kitaplarının yayınlanmasında ve değerlendirilmesinde baskın olan merkeziyetçi tutumun etkisidir (Şimşek ve Dündar, 2017). Bu durumun yanı sıra, geleneksel ve modern toplumlarda birtakım eğilimlerin varlığıdır: "erkeklerin ev dışındaki işlerle meşgul olması beklenirken kadınların ev ile ilgilenmesinin varsayılmasıdır" (Hofstede, 2003, s. 80-1). Bu bağlamda, eğitim sistemleri öğrencilerin toplumsal olarak kabul görmüş cinsiyet rollerini ders malzemeleri yoluyla içselleştirmelerine sebep olmaktadır (Özdoğru, Aksoy, Erdoğan ve Gök, 2006). Bu yüzden, eşit bir cinsiyet temsilinin sağlanmasına ve cinsiyetçi dilin ders kitaplarında önlenmesi konusuna daha fazla dikkat çekilmelidir. Bu bağlamda, Rifkin (1998), ders malzemelerinin sınıf içi kullanımına uygunluğuna karar vermede kullanılacak ölçütlerden birinin cinsiyet eşitliği olması gerektiğini savunmuştur. Yapılan çalışmalar göz önünde bulundurulduğunda, öğrencilerin kitapların içeriğine yönelik ne derece bir eleştirel bakış açısına sahip oldukları üzerinde az durulmuş ve göz ardı edilmiş bir noktadır (Copley, 2017). Yapılan çalışmalarda, hem cinsiyet gösterimlerinin eleştirel bir analizi hem de öğrencilerin ders kitaplarının içeriğine yönelik değerlendirmeleri incelenebilir. 